\title{
Smart City: Studying Smartphone Application Functions with City Marketing Goals Based on Consumer Behavior of Generation $\mathrm{Z}$ in Hungary
}

\author{
Tamás Iványi1*, Szilvia Bíró-Szigeti \\ ${ }^{1}$ Department of Management and Business Economics, Faculty of Economic and Social Sciences, \\ Budapest University of Technology and Economics, H-1521 Budapest, P.O.B. 91, Hungary \\ *Corresponding author, e-mail: ivanyi@mvt.bme.hu
}

Received: 23 April 2018, Accepted: 21 May 2018, Published online: 28 January 2019

\begin{abstract}
Many cities in Hungary have an application specially developed for smartphones that try to satisfy both the needs of tourists and local residents. These "products" are based on different objectives of city marketing and destination marketing: their goal is to make shorter or longer stays more comfortable, provide faster and more personalized information, help consumers to turn their offline experiences into online experience sharing and to provide a platform for two-way communication between local and touristic consumers. In addition to the marketing literature review related to smartphones and local tourism experiences, this paper presents the results of a quantitative questionnaire focusing on the needs of Generation Z concerning application functions. Based on the quantitative results, the members of Generation $Z$ are classified into three main groups with the k-means cluster analysis. Among the groups, there are significant differences between the functional requirements of city marketing applications, and according to the size of the groups three main application types and two main ways of software development can be distinguished. The results also show that there are four main group of functions and connected to the different clusters application functions appear together in the needs of consumers. However, the analysis and comparison of the related data together show also that there are only small differences concerning demographic and device-usage variables between the groups defined by the k-means cluster analysis, and this requires more research methods to be conducted in the future based on the results of this exploratory survey research.
\end{abstract}

\section{Keywords}

city marketing, Generation Z, smartphone application, smart city

\section{Introduction}

The usage of modern and up-to-date mobile application technology has become nowadays an indispensable element of tourism marketing, and in particular city and destination marketing. Today in Hungary more and more local governments recognize the positive effects of the active use of these features of smartphones (Esküdt, 2017), but due to a lack of knowledge of consumer needs and wants, there are many burning issues related to consumer usage of the applications and IT technology. Furthermore, many weakly performing and outdated functionalities are available on the market (e.g. Google Play and iOS App Store). However, many applications (in shorter form apps) and smartphone devices are considered to be one of the pillars of Smart City concepts by the local governments (Z. Karvalics, 2016) and are of the same importance as the development of, for example, sustainable intelligent

transport systems (Kelemen-Erdős, 2012) or a smart road lighting system with adapting capabilities. As a result of this importance, these tools can rearrange the competition between cities and can accelerate the change of positions within the marketing map of the cities (Piskóti, 2017).

While many international and also Hungarian research deal with smartphone applications for different areas, especially for tourism purposes, researches on city marketing applications focusing on the needs of local residents are not typical in recent time despite its importance. There are also a number of research articles (see e.g. Bóta, 2009; Kim and Fesenmaier, 2008; Kenteris et al., 2009) about the instructions of building and designing websites for better user experience, but no such studies have been made in the field of marketing (especially city marketing) for native smartphone applications. Recognizing this problem, this 
research is trying to examine this area of IT management and marketing. This exploratory analysis is intended to raise a number of questions and further research issues. In the course of the study, the methodology is based on former secondary and primary research results by authors and the findings presented in this study were obtained from quantitative primary surveys conducted among Generation $\mathrm{Z}$ consumers.

Using primary research analysis, assuming the different needs of different consumer segments, technology-oriented development directions will be formulated and utilized in practice. One of the key aspects of this article is to identify and to define consumer segments focusing on their main functional needs. Required technology functions are formed into groups, thus creating appropriate product variants per segments. Another key aspect is to determine a marketable software (mobile application platform) and its main elements and features that can work for most smartphone technologies and mobile marketing tools. This way, programming and designing a framework can be created that would serve multiple local governments at once. By oing so and joining other touristic organizations and institutions (e.g. Tourism Destination Managers - TDMs), the development costs could be reduced, as several stakeholders would profit from the application and its platform.

Investigating the consumer needs and buying behavior in tourism concerning smartphone applications can be performed on two different groups of customers. While city marketing applications affect residents and local tourists (people who want to discover and get to know more about their neighborhood), destination marketing is only targeted at "regular" tourists (people who visit that city for only a few days). In the research survey we concentrated on the inhabitants of the city, how can the government change the local tourism and the local everyday life more comfortable, and more attractive to people living in the surroundings. As it is mentioned, studies have not been conducted on this field and on the long-term city experience of locals in contrast to the examination of the touristic (short-term) experience. Assuming that different consumer generations prefer different functions, this analysis covers the mainly younger generations as Generation $\mathrm{Z}$ was interviewed in the questionnaire. During the analysis of the secondary data, two main problems had been set up which were formed into research questions and turned into the main part of the online questionnaire:

1. What kind of consumer clusters can be identified and what are their preferred function requirements?
2. What features and priorities do customers have concerning city marketing application?

\section{Literature review}

\subsection{Understanding, interpreting and categorizing mobile marketing}

The use of a mobile phone, beyond the initial needs for phone calling and messaging, today has become the tool of finding outstanding experience and self-actualization, self-expression (Lai-Katz, 2012). To accomplish this, people use many functions of the phones and install several applications on their devices.

The importance of mobile applications for tourism purposes is emphasized by several studies. According to a survey by the TripAdvisor, for example, $60 \%$ of the users download tourist applications and $45 \%$ is willing to actively use the applications to make travel decisions (Mickaiel, 2011, cited in: Lu et al., 2015). Although there are no similar data and findings for the "local tourism" activities realized by local residents, searching for and enjoying experiences in our own living environment can be interpreted similarly as a touristic trip, but with much lower risk and less "pre-trip" planning. Moreover, the tourist attractions can offer extraordinary experience not only for tourists but locals also (Pomucz and Csete, 2015). The classical threestage touristic buyers decision process - containing previsit, on-site and post-visit phases (Cohen et al., 2014) - is being simplified to a combination of pre-travel and travel phases by the smartphones and joined by fast information searching it provides basically prompt answers to "immediate questions" asked by local tourists (Iványi, 2014). In addition, Kennedy-Eden and Gretzel (2012) point out that a number of additional features can be added to a city-specific mobile application for supporting and informing local residents in a convenient way.

City branding is the interest of numerous local organizations, companies and businesses (Merrilees et al., 2012), in which they can utilize each other's strengths to jointly reinforce the positive awareness gained by the city. The development of a smartphone application can also be part of the city branding strategy, for which we can see many cases in Hungary (for example, in Szentendre's "Irány Szentendre!" - "Let's go to Szentendre!" application). As a result of the software development, other stakeholders (such as IT businesses) are involved directly in city marketing in addition to tourism organizations and local governments, therefore more contributors can profit from the process through their successful applications. There are 
various elements and diverse aspects of city branding (Ashworth, 2009; Soltani et al., 2018), which include, for example, the definition of the city's personality, signature building and design, event hallmarking, and the unique tailor-made formulation of events based on local history and legends (Faragó, 2015).

As a consequence of expeditious smartphone development, a number of new marketing solutions appeared recently, commonly referred to as mobile marketing. This has been defined by Kaplan (2012:p.130) as it includes "any marketing activity conducted through a ubiquitous network (Internet of Things - IoT) to which consumers are constantly connected using a personal mobile device (like a smartphone)". Connectivity is not only the basis for mobile marketing but also for the Smart City concept (Piskóti, 2017).

Kaplan (2012) proposes two main dimensions for defining four disjoint categories to group mobile marketing tools:

1. On the one hand, we can examine the degree of user knowledge. That is the amount of information we have on the consumer when the message is created, it tells us to what extent the message is personalized. Depending on the complexity of software development, content that appears in smartphone applications can be customized automatically - such as semantic web solutions (Berners-Lee et al., 2001). In simpler and more cost-effective cases, single and impersonalized content can be also used in applications, or as an intermediate solution a personalization onboarding process can be provided for the user.

2. On the other hand, based on the trigger of communication we can distinguish push and pull mobile marketing. While in the case of smartphones, when the application is opened and in an active state communication is pull-initiated, notifications sent to the smartphones are a push form of communication.

Although mobile marketing involves a number of mobile phone solutions (e.g. SMS, e-mail, MMS), in most cases, we understand smartphone applications for this term. Kennedy-Eden and Gretzel (2012) point out that smartphone applications can be grouped along a number of dimensions. Several taxonomies can be found to systematize and group mobile applications, among others Dombroviak and Ramnath (2007), Heinonen and Pura (2008), and Nickerson et al. (2013) proposed different dimensions to create taxonomies. These classifications also include the degree of interactions, consumer-orientation and characteristics of applications. Based on these general classifications Kennedy-Eden and Gretzel (2012) introduced the classification of tourism-related applications. Local residents and tourists often find a similar experience and encounter almost the same situations through the user experience created by the applications. Thus, taxonomy used for classifying applications for tourism purposes can be adapted to urban mobile marketing applications almost without any conversion.

Kaplan (2012) classifies mobile marketing applications into four separated groups depending on the location-sensitivity and time-sensitivity of the information provided. The four groups are:

1. quick timers: time-sensitive but not location-sensitive, this includes the traditional social media, with functions based on immediacy;

2. slow-timers: neither location- nor time-sensitive, including traditional social media sites based on invariable content;

3. space-timers: take account of time and place simultaneously, including applications based on messaging about a specific time and location;

4. space-locators: location-sensitive but not time-sensitive, including applications based on messages related to a specific place, but the time of reading it is not important.

City-based mobile applications, though by their very nature, are essentially location-sensitive, can be grouped in all four categories, whether used for tourist purposes or as a local resident. Time-sensitivity is important for events, news, and temporary changes in information, but the presentation of attractions, city walks, and the basic features of the place is time-independent content. Certain features are location-sensitive, however, as regarding general information, the content is invariable, so browsing through these features is available at a different location too or even during the pre-travel phase.

It should be emphasized that, according to the models and taxonomies presented above, there are several city or destination marketing applications that can be grouped into more than one categories. In addition, there are many applications that originally are not designed for city or destination marketing purposes, but during information gathering they provide a similar functionality for both the local residents and tourist, therefore these applications may be displayed as substitute products (Lu et al., 2015). 


\subsection{The importance of the applications for Generation $\mathbf{Z}$}

Hannam et al. (2006) point out that due to apps and smartphones, the borders between the usage of these technologies for general, every day and touristic purposes are increasingly fading and disappearing. Wang et al. (2016) reveal that the functions used in tourism and everyday life can not be interpreted as separate categories, but as a special case of each other. For example, based on Lash and Ury's (1994, cited by: Wang et al., 2016) finding that "tourism-related" activities appear in our daily life besides "work-related" activities, the importance of local tourism and tourism experience in people's own neighborhood can be interpreted. They also argue that the concept of tourism and the tourism archetype had been completely transformed over the last decades from the classical perspectives of the tourist experiences that emphasized the escape from everyday activities.

In this research paper the focus is specifically on the needs of Generation Z, also called as the iGeneration (or iGen), which generation was defined among other by Howe and Strauss (1991). Generation Z, consisting of those who were born between 1995 and 2010, is a more online than offline generation. Gursoy et al. (2008) examines the generational differences specialized to the field of hospitality. Hack-Handa and Pintér (2015) point out that $87 \%$ of them are Internet users through smartphones (compared to Generation X - born between 1961 and 1981 - for which it is only $50 \%$ ) and they download almost twice as many smartphone applications monthly as Generation $X$. The members of the iGeneration use in high intensity for example social networking sites, maps and navigation, music and weather data applications that can be categorized into the seven main groups of tourism applications proposed by Kennedy-Eden and Gretzel (2012) taxonomy: Navigation, Social, Mobile Marketing, Security / emergency, Transactional, Information, Entertainment (see in more details below in Table 1, column 1).

Generation Z or N-generation (net generation) (Prensky, 2001) is characterized by the fact that they started to use the Internet and computers at the era of Web 2.0 (BernersLee et al., 2001) when user generated content creation appeared besides high intensity of information gathering (Nagy and Fazekas, 2016). Therefore, Generation Z is seeking for and using applications that besides providing information supports also the generation of information, thus, the members can have a constant two-way communication connection between each other. However, applications and the use of the smartphone affect not just the consumer behavior of the Generation $\mathrm{Z}$, but it also influences and changes their everyday schedule. According to the Hungarian Youth Survey in 2012 (called "Magyar Ifjúság 2012", see in Székely, 2013), due to excessive free time spent online, today's young people are going out less frequently and they have limited knowledge for example about their surroundings, and they spend barely any time in cultural institutions. Thus, the role of city-marketing apps is becoming even more important, as these can offer online content that can encourage the N-generation to spend their free time outside and get to know local values.

Hardey (2011) proposes a non-age-related, but rather behavior-related generation classification using the letter $\mathrm{C}$ that correlates highly with Generations Z. C stands mainly for content creation, but is supported by additional C's: Creativity, Casual Collapse, Control, and Celebrity. According to the Eurobarometer 2015 survey about the most popular online activities, $86 \%$ of the group of 15-24 aged youngsters like to use the community based social networking sites that offer content creation. This is a much higher proportion than the general $60 \%$ percent concerning the same activity for the "older than 15 years" group in the survey (Nagy and Fazekas, 2016). So, based on their behavior there are much more members of Generation $\mathrm{C}$ among the 15-24 years old youngsters than among the older people. Kim et al. (2015) reminds that social media has an increasingly important influence on (local) tourism, especially for younger generations. While there is no difference in the rate of influence of most of the factors such as the destination's website or the more general (e.g. Google) and thematic (e.g. TripAdvisor) search pages, the impact of social media (social networking sites, forums, and video and image sharing sites) differs widely between generations. These social media sites are the most important platforms for Generation $\mathrm{C}$ because they can create content, collaborate, rate and review content a curate other members contents.

Concerning the importance of smartphone applications in everyday life and in tourism too Wang et al. (2016) emphasizes, that in many cases smartphones can replace desktops or laptops for small tasks, can provide more information search activity and more communication with family and friends. For example, in the field of (local) tourism or in everyday administration, these can offer comfort, flexibility, constant connectivity, a better user experience, or even "on-the-go" planning and sharing of experiences.

The analysis of Generation $\mathrm{Z}$ also points out the utmost importance of mobile phone applications, according to Hack-Handa and Pintér (2015). Members of Generation Z are downloading and using applications from a lot more 
(pre-defined) categories than older generations, so the use of smartphones appear in many areas of their everyday life.

\section{Methodology}

Based on the results of previous researches by the author a questionnaire survey had been conducted to collect information about the most important functions for Generation $\mathrm{Z}$ regarding a city marketing mobile application. The target population was the members of Generation $\mathrm{Z}$ (over 18 years) who live in a city or a district where city marketing applications are available. Snowball sampling method and an online questionnaire software (Limesurvey 2.64.7) was used to collect the answers. This online software provides a wide variety of question types and also has an advanced system of creating conditions.

Sampling was done in two consecutive periods with two different target groups. The first one was a test query that took place between 2017-06-08 and 2017-06-20, when 122 evaluable responses were received. The target group was a diverse group according to age and place of residence. The second sampling was based on a more homogeneous group between 2017-12-17 and 2017-12-19, where members of Generation $\mathrm{Z}$ - mainly university students from Budapest and major Hungarian cities - were asked. In this case 412 valuable answers were received and analyzed. The questions and the survey structure and logic during the two periods of the sampling were identical.

Based on the secondary research (mainly Iványi, 2014; Kennedy-Eden and Greztel, 2012; Wang et al., 2016), a list of features was compiled for the first period of the sampling and based on the results no changes were accomplished for the second period. Fifteen functions that were found in several already released Hungarian city marketing applications and the most frequently mentioned functions in previous researches were selected for the questionnaire's list. These functions and features are listed in Table 1 with a brief description and examples available at Google Play software marketplace for Android in March 2018.

Besides collecting the demographic, device usage and application-knowledge data with the survey, a two steps priority ranking solution was developed for the fifteen functions that were included.

Table 1 The explanation and list of functions included in the survey

\begin{tabular}{|c|c|c|c|}
\hline Function category & Function / feature & Explanation & Example \\
\hline Information & Local sights & $\begin{array}{l}\text { Brief description of buildings, sculptures and institutions in the } \\
\text { area, with pictures and basic information }\end{array}$ & Hegyvidék \\
\hline Entertainment & Walking tours & Multi-step guided tour with text or audio & explorEGER \\
\hline Information & $\begin{array}{l}\text { Local government } \\
\text { information }\end{array}$ & $\begin{array}{l}\text { General, invariable information on local government, e.g. office } \\
\text { hours, representatives, delegates }\end{array}$ & Zugló App \\
\hline $\begin{array}{l}\text { Transactional / } \\
\text { Security, emergency }\end{array}$ & $\begin{array}{l}\text { Electronic helpdesk, } \\
\text { administration }\end{array}$ & $\begin{array}{l}\text { Online administration, request for ID, passport and other papers, } \\
\text { appointment booking }\end{array}$ & OkmányApp \\
\hline $\begin{array}{l}\text { Mobile marketing / } \\
\text { Navigation }\end{array}$ & List of local services, shops & $\begin{array}{l}\text { A categorized list of shops in the given area with basic } \\
\text { information }\end{array}$ & I love Dunakanyar \\
\hline $\begin{array}{l}\text { Mobile marketing / } \\
\text { Transactional }\end{array}$ & Special offers of local shops & $\begin{array}{l}\text { Temporary offers of shops in the given area (as paid } \\
\text { advertisement) }\end{array}$ & Zalaapp \\
\hline $\begin{array}{l}\text { Mobile marketing / } \\
\text { Transactional }\end{array}$ & Local discounts & $\begin{array}{l}\text { Permanent discounts for the residents of the given area and } \\
\text { loyalty/discount card service }\end{array}$ & Józsefváros \\
\hline $\begin{array}{l}\text { Entertainment / } \\
\text { Mobile marketing }\end{array}$ & Local events & Events, festivals, programs in the near future & Balatonfüred \\
\hline Entertainment & $\begin{array}{l}\text { Local video and image } \\
\text { collection }\end{array}$ & Photos or videos related to local attractions & Somogy \\
\hline Information & Local news & $\begin{array}{l}\text { Local news related to local government and the given area, e.g. } \\
\text { changes in traffic }\end{array}$ & Budapest XIII \\
\hline Security, emergency & Fault reporting & $\begin{array}{l}\text { Report a problem like public lighting, blackout, potholes or other } \\
\text { relevant to local government }\end{array}$ & KőbányApp \\
\hline Navigation & Maps & Maps of the given area related to sights or shops & Budaörs \\
\hline $\begin{array}{l}\text { Navigation / } \\
\text { Transactional }\end{array}$ & Mobile parking & $\begin{array}{l}\text { Parking information, maps of the parking zones, payment } \\
\text { facilities online or through mobile phone invoice }\end{array}$ & Irány Szentendre! \\
\hline Entertainment & Gamification & $\begin{array}{l}\text { E.g. gamified walking tour, memory game with pictures related } \\
\text { to the city }\end{array}$ & Irány Szentendre! \\
\hline Social & $\begin{array}{l}\text { Bulletin board, user to user } \\
\text { messaging }\end{array}$ & $\begin{array}{c}\text { Communicating with other users of the application, review } \\
\text { option of the elements, submitting public feedback }\end{array}$ & Debrecen App \\
\hline
\end{tabular}


In the first step, out of the 15 functions, up to 8 functions could be selected in a multiple-choice question that were said to be needed by the user. Then, in the next step, a ranking question had to be solved by the user containing just the previously selected items.

The relationship between the distinct consumer groups and the function selections was analyzed by the method of k-center clustering. For the clustering and the correlation analysis scale transformation and variable respecification were evaluated and dummy variables were defined. Two dummy variables were created for each of the selected mobile application features: one variable determined whether the feature was selected in the first phase of the ranking, and the second dummy variable showed whether the user put the feature in the first part or the second part of the ranking during the second phase. This variable respecification and using dummy values is based on the general method presented by Sajtos and Mitel (2007) and the method used by for example Sági (2010). The clustering process and the statistical evaluation were made in IBM SPSS 25 using the built-in k-means function, visualizations were created with R Studio using GNU licensed R Statistics 3.4.4.

\section{Results}

To evaluate the results, the previously mentioned two samples were concatenated together into one database and only adult aged members of Generation $\mathrm{Z}$ responses were selected. From 18 to 22 years old users 453 evaluable responses were collected. Although age distribution is not quite homogenous, because of the narrow age range, weighting results according to age was not performed. The gender ratio was almost equal, $49 \%$ men and $51 \%$ women filled out the questionnaire. $53 \%$ of the sample were residents of Budapest, where many districts already have city marketing smartphone applications, while $34 \%$ of the users are living in a county seat or in a city that also has such an application.

Table 2 shows the rate of choosing each function for whole sample. Since local video and image collection, bulletin boards, chat and gamification features were considered necessary by less than $15 \%$ of the sample, therefore, the values associated with these functions were not taken into account and used for cluster analysis or for correlation matrix and statistical tests based on correlations. The values were taken into consideration for the walking tours, assuming that there should be a correlation between sightseeing walks and local attractions.

Based on the numerical transformation of the two-step evaluation presented in Section 3, a correlation analysis was performed among the twelve functions, as shown in Fig. 1.

From the correlation matrix, it has become apparent that certain functions are likely to appear together more frequently and emerge into groups, while some functions' occurrence is opposite to the needs of other functions, so based on these findings performing a cluster analysis of the function's importance data was resolved.

The function correlation matrix was transformed to a distance matrix for performing hierarchical cluster

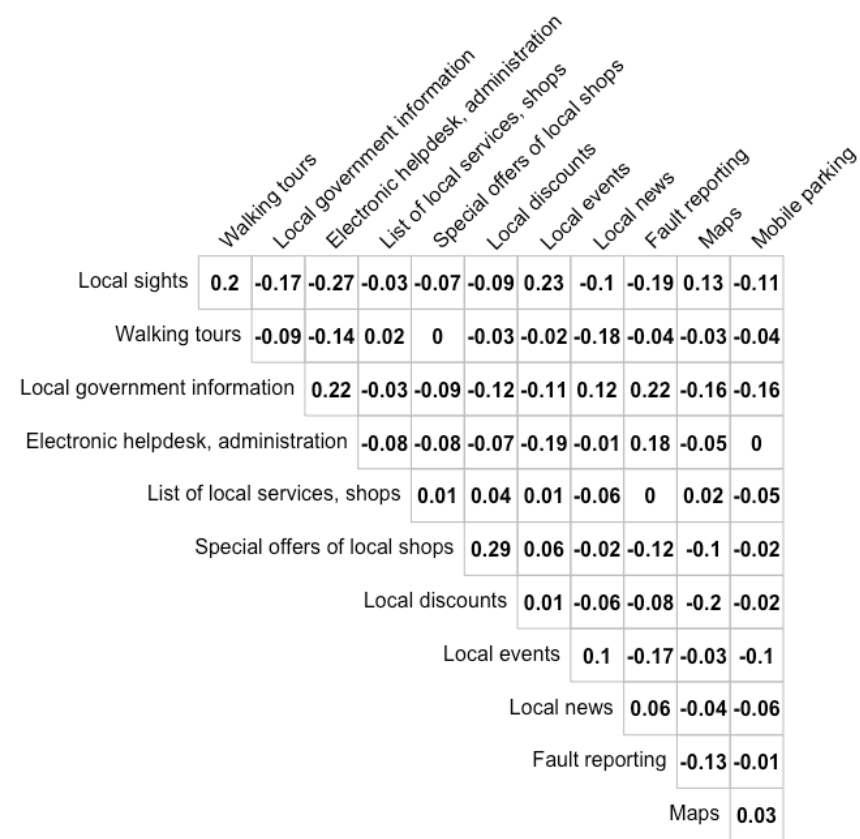

Fig. 1 The correlation matrix of the functions 
Table 2 The percentage of necessity of the functions

\begin{tabular}{lc} 
Local events & $81 \%$ \\
Local sights & $70 \%$ \\
List of local services, shops & $68 \%$ \\
Maps & $68 \%$ \\
Local news & $60 \%$ \\
Electronic helpdesk, administration & $53 \%$ \\
Mobile parking & $52 \%$ \\
Local government information & $51 \%$ \\
Fault reporting & $45 \%$ \\
Local discounts & $33 \%$ \\
Special offers of local shops & $23 \%$ \\
Walking tours & $16 \%$ \\
Local video and image collection & $12 \%$ \\
Bulletin board, user to user messaging & $11 \%$ \\
Gamification & $3 \%$ \\
\hline
\end{tabular}

analysis of the functions and multidimensional scaling (MDS). In Fig. 2 the results of the hierarchical clustering are shown. The complete linkage method was used for the analysis. The list of selected functions based on Kennedy-Eden and Gretzel (2012) and Iványi (2014) was divided into 4 main groups according to the vertical icicle diagram:

1. Touristic features with less time-sensitivity but high level of experience - local events and local sights.

2. Features that are neutral in terms of experience and everyday administration - these are mainly the local shops, services, discounts and special offers.

3. Administration features - Local and electronic customer service solutions that help to solve everyday problems including relatively invariable information.

4. Navigation features - counting maps and mobile parking.
Also, as a result, the two-dimensional map of application feature's perception, shown in Fig. 3, was obtained from 3D MDS data. Similar to the mobile application grouping by Kaplan (2012) the vertical axis shows the time-sensitivity of the functions with general-invariable information and temporary information at the endpoints of the axis. Along the horizontal axis, touristic-experiences and everyday life administration can be recognized as the two opposite endpoints. The identified four major groups of the hierarchical clustering are also marked in the MDS results (see Fig. 2 and Fig. 3).

As a result of the k-means cluster analysis of the Generation $\mathrm{Z}$ sample, three groups were formulated with a size of 107, 171 and 175 members, so that their distribution is approximately $23.6 \%, 37.7 \%$ and $38.6 \%$ in the sample.

Table 3 shows the percentage of how important the features were in each cluster. This importance classification was defined by the two dummy values that the clustering was based on. The most important functions in each cluster are highlighted.

As a result of cross-table analysis between clusters, the male-female ratio is homogeneous (for the Chi-square test $\mathrm{p}$ value is 0.338 ). There are also no significant differences concerning smart device usage. For smartphones, Android and $\mathrm{iOS}$ devices are approximately half the sizes of each of the three clusters (Chi-square test for the crosstable gives 0.861 for the $p$ value), and only in the case of tablets, the first cluster is where $\mathrm{iOS}$ is dominant ( $67 \%$ of the members use iOS tablet and Android devices have only $33 \%$ ranked as the second, and for the tablets the Chi-square test provides 0.063 for the $\mathrm{p}$ value).

The first group can be called "smart information seekers of everyday life". The application is used in addition to gather information about local events, nearby shops, services and temporary deals, sales and discounts as well as

Hierarchical clustering of functions for the whole sample

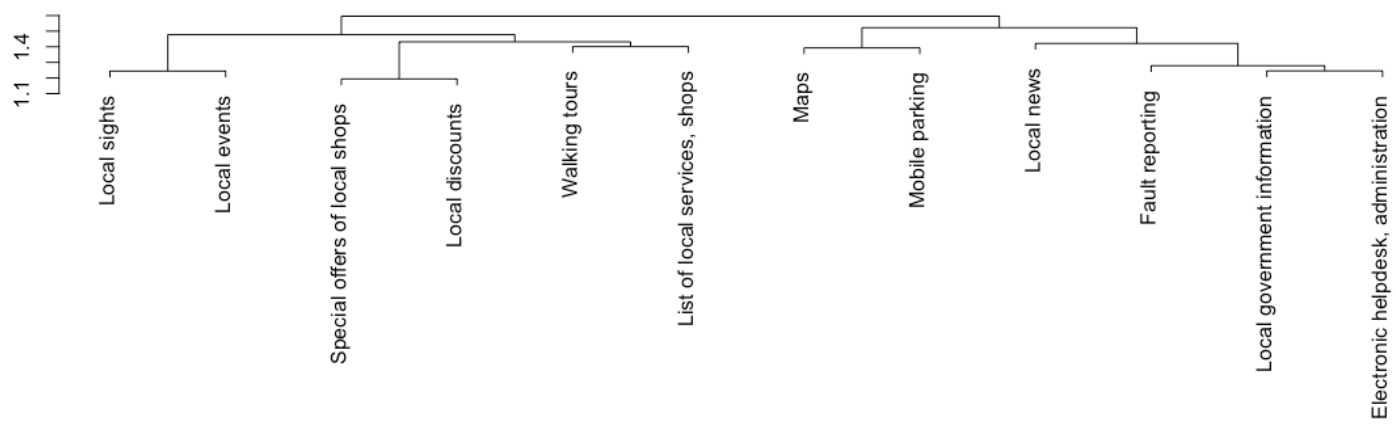

Fig. 2 Hierarchical clustering of the functions for the whole sample 
Function perception map for the whole sample

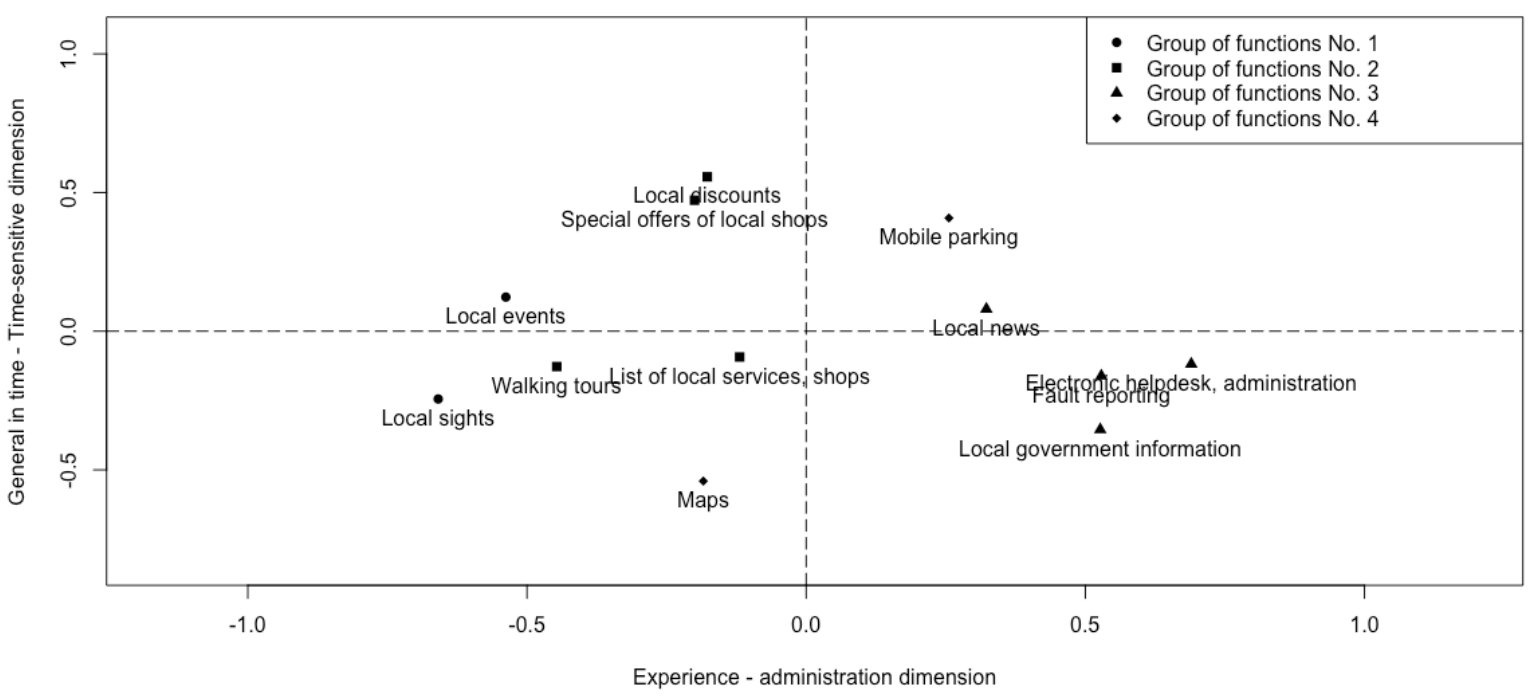

Fig. 3 Function perception map for the whole sample

Table 3 The explanation and list of functions included in the survey

\begin{tabular}{|c|c|c|c|c|c|c|c|c|c|c|}
\hline \multirow{2}{*}{\multicolumn{2}{|c|}{$\begin{array}{l}\text { Group of function number and name of } \\
\text { the function }\end{array}$}} & \multicolumn{9}{|c|}{ Cluster No. } \\
\hline & & \multicolumn{3}{|c|}{1} & \multicolumn{3}{|c|}{2} & \multicolumn{3}{|c|}{3} \\
\hline \multicolumn{2}{|c|}{ Size of the cluster: } & \multicolumn{3}{|c|}{$23.60 \%$} & \multicolumn{3}{|c|}{$37.70 \%$} & \multicolumn{3}{|c|}{$38.60 \%$} \\
\hline \multicolumn{2}{|c|}{ Importance of the function: } & $\begin{array}{l}\text { Not } \\
\text { imp. }\end{array}$ & $\begin{array}{c}\text { Somewhat } \\
\text { imp. }\end{array}$ & $\begin{array}{l}\text { Really } \\
\text { imp. }\end{array}$ & $\begin{array}{l}\text { Not } \\
\text { imp. }\end{array}$ & $\begin{array}{l}\text { Somewhat } \\
\text { imp. }\end{array}$ & $\begin{array}{l}\text { Really } \\
\text { imp. }\end{array}$ & $\begin{array}{l}\text { Not } \\
\text { imp. }\end{array}$ & $\begin{array}{c}\text { Somewhat } \\
\text { imp. }\end{array}$ & $\begin{array}{l}\text { Really } \\
\text { imp. }\end{array}$ \\
\hline 1 & Local sights & $40.2 \%$ & $46.7 \%$ & $13.1 \%$ & $36.8 \%$ & $57.3 \%$ & $5.8 \%$ & $4.0 \%$ & $28.0 \%$ & $68.0 \%$ \\
\hline 2 & Walking tours & $87.9 \%$ & $8.4 \%$ & $3.7 \%$ & $88.9 \%$ & $9.4 \%$ & $1.8 \%$ & $71.4 \%$ & $23.4 \%$ & $5.1 \%$ \\
\hline 3 & Local government information & $59.8 \%$ & $32.7 \%$ & $7.5 \%$ & $22.8 \%$ & $33.9 \%$ & $43.3 \%$ & $64.0 \%$ & $28.6 \%$ & $7.4 \%$ \\
\hline 3 & Electronic helpdesk, administration & $55.1 \%$ & $34.6 \%$ & $10.3 \%$ & $16.4 \%$ & $24.0 \%$ & $59.6 \%$ & $69.1 \%$ & $30.3 \%$ & $0.6 \%$ \\
\hline 2 & List of local services, shops & $35.5 \%$ & $27.1 \%$ & $37.4 \%$ & $33.3 \%$ & $50.9 \%$ & $15.8 \%$ & $21.7 \%$ & $58.9 \%$ & $19.4 \%$ \\
\hline 2 & Special offers of local shops & $55.1 \%$ & $33.6 \%$ & $11.2 \%$ & $94.7 \%$ & $4.1 \%$ & $1.2 \%$ & $85.7 \%$ & $13.1 \%$ & $1.1 \%$ \\
\hline 2 & Local discounts & $29.9 \%$ & $42.1 \%$ & $28.0 \%$ & $90.1 \%$ & $9.9 \%$ & $0.0 \%$ & $90.3 \%$ & $9.1 \%$ & $0.6 \%$ \\
\hline 1 & Local events & $21.5 \%$ & $29.9 \%$ & $48.6 \%$ & $22.8 \%$ & $63.2 \%$ & $14.0 \%$ & $8.0 \%$ & $48.0 \%$ & $44.0 \%$ \\
\hline$-*$ & Local video and image collection & $90.7 \%$ & $9.3 \%$ & $0.0 \%$ & $91.2 \%$ & $8.2 \%$ & $0.6 \%$ & $80.0 \%$ & $15.4 \%$ & $4.6 \%$ \\
\hline 3 & Local news & $49.5 \%$ & $23.4 \%$ & $27.1 \%$ & $31.6 \%$ & $34.5 \%$ & $33.9 \%$ & $41.1 \%$ & $39.4 \%$ & $19.4 \%$ \\
\hline 3 & Failure reporting & $76.6 \%$ & $19.6 \%$ & $3.7 \%$ & $24.0 \%$ & $36.8 \%$ & $39.2 \%$ & $67.4 \%$ & $28.0 \%$ & $4.6 \%$ \\
\hline 4 & Maps & $54.2 \%$ & $31.8 \%$ & $14.0 \%$ & $29.2 \%$ & $38.6 \%$ & $32.2 \%$ & $9.7 \%$ & $36.6 \%$ & $53.7 \%$ \\
\hline 4 & Mobile parking & $43.9 \%$ & $39.3 \%$ & $16.8 \%$ & $48.5 \%$ & $38.6 \%$ & $12.9 \%$ & $56.0 \%$ & $33.7 \%$ & $10.3 \%$ \\
\hline$-*$ & Gamification & $96.3 \%$ & $3.7 \%$ & $0.0 \%$ & $98.2 \%$ & $1.2 \%$ & $0.6 \%$ & $96.6 \%$ & $3.4 \%$ & $0.0 \%$ \\
\hline$-*$ & $\begin{array}{l}\text { Bulletin board, user to user } \\
\text { messaging }\end{array}$ & $89.7 \%$ & $7.5 \%$ & $2.8 \%$ & $88.3 \%$ & $10.5 \%$ & $1.2 \%$ & $89.7 \%$ & $8.6 \%$ & $1.7 \%$ \\
\hline
\end{tabular}

* These features were not included in the correlation analysis because of the low percentage of choosing the item

using mobile parking by the members of this group. For them function group no. 2 is important from the hierarchical clustering.

The second cluster is called "convenient administration" based on the most significant features, and for the members it is most important to be provided local government news as a local resident, to reach online customer service, to get help to solve local problems quickly and efficiently, such as failure reporting. Local attractions, events, maps are less important to them than for the members of the other groups. In this cluster function group no. 3 is dominant based on the hierarchical clustering.

The third - and at the same time the largest - cluster can be called "unique experience-seeking local tourists". 
For them, local attractions are particularly important, and although sightseeing walking tours received quite a moderate level of importance for this group too, the same value evaluated for the other two clusters is much lower than for this group. Interest in local events was also stated by almost every member of the cluster and most often was ranked for the first or the second place. In many cases, local sights and walking tours are combined with maps feature - these can be interactive, dynamically created by smartphone technologies. Here function group no. 1 was dominant from the hierarchical clustering, but also maps and local shops appear to be important from the other function groups.

For the testing of the distribution difference of importance among the clusters Kruskal-Wallis test was performed, the significance level of the differences is shown in Table 4. The analysis was performed to understand the differences between the clusters based on the twelve functions where one or more of the values were at least $15 \%$.

The significance level is over $5 \%$ only for mobile parking and list of local shops and services. According to Table 3 basic information of local shops and services appear to be important in more than one cluster, so it can be generally an important factor for the locals. Mobile parking is probably a much more important factor for the older generations and that is why there is no significant difference among the clusters of Generation $\mathrm{Z}$.

\section{Conclusions and managerial implications}

The delegates of a number of local governments argue that smartphone applications developed for both local residents and tourists are playing an important role in their smart city concept, which is at the center of thinking for more and more cities. The literature review shows that although smartphone applications reach most of the generations, yet the most important of these groups are the most enthusiastic application users, the $\mathrm{N}$-generation, thus they are the most common consumers of smartphone apps.

As a finding of the research, it was revealed that three distinct groups can be identified among the members of Generation $\mathrm{Z}$ asked in this survey. These groups are based on application features supporting purchasing, tourism experience and administrative tasks. As a result of the correlation analysis of functions, it is also apparent that there is a stronger negative correlation between certain functions and function groups (for example between administration and tourism experience). This result points out that applications for consumers and especially young people
Table $4 \mathrm{P}$ value results of Kruskal-Vallis test for the features

\begin{tabular}{lc}
\hline Smartphone application feature & P value \\
\hline Local events & $<0.0005$ \\
Local sights & $<0.0005$ \\
List of local services, shops & 0.055 \\
Maps & $<0.0005$ \\
Local news & 0.008 \\
Electronic helpdesk, administration & $<0.0005$ \\
Mobile parking & 0.088 \\
Local government information & $<0.0005$ \\
Failure reporting & $<0.0005$ \\
Local discounts & $<0.0005$ \\
Special offers of local shops & $<0.0005$ \\
Walking tours & $<0.0005$ \\
\hline
\end{tabular}

are considered not as multifunctional solutions, but as tools that focus on making convenient specific areas.

Compared with previous research results, applications that had been already developed and released so far include more than one set of functions. In most cases these applications follow existing patterns, schemas, but these are not coherent with the results presented in this paper. Two main directions of development can be suggested:

1. Creating a complex application with large investment costs, which also serves more than one of the identified clusters, so it includes several function groups. In this case an application onboarding process is required, based on which the later available content can be personalized for the user. This is in accordance with the user knowledge dimension of the mobile marketing classification by Kaplan (2012).

2. On the other hand local governments can try to create separate "targeted applications" for each cluster, thus require a smaller investment and provide a smaller target market, but these can implement a much more tailor-made service based on the needs of the users concerned. In this case, it is recommended to use the size ratios of the clusters that are defined in the function groups presented in the results for calculating the size of the future target market.

It seems that both of the proposed solutions and development directions can be applied for the Hungarian city marketing smartphone applications using schemas and common application backend framework development, as it was mentioned in the introduction. Schemas can also help to reduce development costs and it is important 
especially when both Android and iOS software have to be programmed. According to the survey results it is compulsory to develop for both operation systems in each identified cluster, so the costs of the adaptation from one system to the other can be balanced by using schemas.

\section{Limitations and future plans}

Although the research and the findings of this paper is very limited, it only partly applies to Generation $\mathrm{Z}$ and can not be considered as representative, neither for this specific generation, but due to the exploratory nature of the research, it may lead to further research questions. In the future, it is worth to conduct researches about the business to business part of the development and perform depth interviews concerning local governments and IT businesses. It is important also to understand the motivations

\section{References}

Ashworth, G. J. (2009) "The Instruments of Place Branding: How is it Done?", European Spatial Research and Policy, 16(1), pp. 9-22. https://doi.org/10.2478/v10105-009-0001-9

Berners-Lee, T., Hendler, J., Lassila, O. (2001) "The Semantic Web", Scientific American, 284(5), pp. 34-43.

https://doi.org/10.1038/scientificamerican0501-34

Bóta, L. (2009) "Web page navigation analyses for marketing management decision-making", Periodica Polytechnica Social and Management Sciences, 17(2), pp. 89-95.

https://doi.org/10.3311/pp.so.2009-2.05

Cohen, S. A., Prayag, G., Moital, M. (2014) "Consumer behaviour in tourism: Concepts, influences and opportunities", Current Issues in Tourism, 17(10), pp. 872-909. https://doi.org/10.1080/13683500.2013.850064

Dombroviak, K. M., Ramnath, R. (2007) "A Taxonomy of Mobile and Pervasive Applications", In: SAC '07 Proceedings of the 2007 ACM symposium on Applied computing, Seoul, Korea, pp. 1609-1615. https://doi.org/10.1145/1244002.1244345

Esküdt, V. (2017) "Városmarketing felmérés 2017" (City marketing survey results 2017), presented at Márkaépítés 2017 conference, Budapest, Hungary, May 30, 2017. (in Hungarian)

Faragó, H. (2015) "Települések és rendezvények" (Cities and events), presented at Márkaépítés 2015 - Városmarketing Conference, Budapest, Hungary, May, 28, 2015. (in Hungarian)

Gursoy, D., Maier, T. A., Chi, C. G. (2008) "Generational differences: An examination of work values and generational gaps in the hospitality workforce", International Journal of Hospitality Management, 27(3), pp. 448-458. https://doi.org/10.1016/j.ijhm.2007.11.002

Hack-Handa, J., Pintér, R. (2015) "Generációs különbségek a magyar médiafogyasztásban" (Generational differences in Hungarian media consumption), Információs társadalom, 15(2), pp. 7-17. (in Hungarian) [online] Available at: http://epa.oszk. hu/01900/01963/00048/pdf/EPA01963_informacios_tarsadalom_2015_2_007-017.pdf [Accessed: 20 April 2018]. of the TDM (tourism destination manager) organizations and to compare their objectives and the important functions of the discovered clusters. The observation of consumer behavior also needs to be extended to other generations in the future, enabling the results to be widened to compare the needs and wants of different age groups concerning smartphone applications. It is also an important question how a smartphone application can be interpreted concerning the classical product development process and the product level model of marketing.

\section{Acknowledgement}

㭋 "Supported by the ÚNKP-17-3-I. New National "Excellence Program of the Ministry of Human Capacities."

Hannam, K., Sheller, M., Urry, J. (2006) "Editorial: Mobilities, Immobilities and Moorings", Mobilities, 1(1), pp. 1-22. https://doi.org/10.1080/17450100500489189

Hardey, M. (2011) "Generation C: Content, Creation, Connections and Choice", International Journal of Market Research, 53(6), pp. 749-770. https://doi.org/10.2501/IJMR-53-6-749-770

Heinonen, K., Pura, M. (2008) "Classifying Mobile Services", All Sprouts Content, 6(42), 160. [online] Available at: https://aisel. aisnet.org/sprouts_all/160 [Accessed: 20 April 2018].

Howe, N., Strauss, W. (1991) "Generations: The History of America's Future, 1584 to 2069", 1st ed., William Morrow \& Company, New York, USA.

Iványi, T. (2014) "Korszerü mobiltechnológiák alkalmazása a városmarketingben" (Using up-to-date mobile technologies in city marketing), In: Keresztes, G. (eds.) Tavaszi Szél 2016 2. kötet (Spring Wind 2016 Volume 2), Doktoranduszok Országos Szövetsége, Budapest, Hungary, pp. 301-317. (in Hungarian)

Kaplan, A. M. (2012) "If you love something, let it go mobile: Mobile marketing and mobile social media 4x4", Business Horizons, 55(2), pp. 129-139.

https://doi.org/10.1016/j.bushor.2011.10.009

Kelemen-Erdős, A. (2012) "Sustainable public transport: A Central European Study", Periodica Polytechnica Social and Management Sciences, 20(2), pp. 81-90.

https://doi.org/10.3311/pp.so.2012-2.03

Kennedy-Eden, H., Gretzel, U. (2012) "A Taxonomy of Mobile Applications in Tourism", e-Review of Tourism Research, 10(2), pp. 47-50. [online] Available at: http://agrilife.org/ertr/ files/2012/11/eRTR_SI_V10i2_Kennedy-Eden_Gretzel_47-50.pdf [Accessed: 20 April 2018]

Kenteris, M., Gavalas, D., Economou, D. (2009) "An innovative mobile electronic tourist guide application", Personal and Ubiquitous Computing, 13(2), pp. 103-118. https://doi.org/10.1007/s00779-007-0191-y 
Kim, H., Fesenmaier, D. R. (2008) "Persuasive Design of Destination Web Sites: An Analysis of First Impression", Journal of Travel Research, 47(1), pp. 3-13.

https://doi.org/10.1177/0047287507312405

Kim, H., Xiang, Z., Fesenmaier, D. R. (2015) "Use of The Internet for Trip Planning: A Generational Analysis", Journal of Travel \& Tourism Marketing, 32(3), pp. 276-289. https://doi.org/10.1080/10548408.2014.896765

Lai, C.-H., Katz, J. E. (2012) "Are we evolved to live with mobiles? An evolutionary view of mobile communication", Periodica Polytechnica Social and Management Sciences, 20(1), pp. 45-54. https://doi.org/10.3311/pp.so.2012-1.05

Lu, J., Mao, Z., Wang, M., Hu, L. (2015) "Goodbye maps, hello apps? Exploring the influential determinants of travel app adoption", Current Issues in Tourism, 18(11), pp. 1059-1079. https://doi.org/10.1080/13683500.2015.1043248

Merrilees, B., Miller, D., Herington, C. (2012) "Multiple stakeholders and multiple city brand meanings", European Journal of Marketing, 46(7/8), pp. 1032-1047. https://doi.org/10.1108/03090561211230188

Nickerson, R. C., Varshney, U., Muntermann, J. (2013) "A method for taxonomy development and its application in information systems", European Journal of Information Systems, 22(3), pp. 336-359. https://doi.org/10.1057/ejis.2012.26

Nagy, Á., Fazekas A. (2016) "Offline helyett online szabadidő?" (Online free time instead of offline free time?), Médiakutató, 16(2), pp. 41-57. (in Hungarian) [online] Available at: http://mediakutato. hu/cikk/2016_02_nyar/03_offline_helyett_online_szabadido.pdf [Accessed: 20 April 2018]

Piskóti, I. (2017) "Vonzóbb lesz-e az okosabb város?" (Will be the smarter cities more attractive?), presented at Smart City - Smart Marketing Conference, Kecskemét, Hungary, Dec. 05, 2017. (in Hungarian)

Pomucz, A. B., Csete, M. (2015) "Sustainability Assessment of Hungarian Lakeside Tourism Development", Periodica Polytechnica Social and Management Sciences, 23(2), pp. 121-132.

https://doi.org/10.3311/PPso.7506
Prensky, M. (2001) "Digital Natives, Digital Immigrants Part 1", On the Horizon, 9(5), pp. 1-6. https://doi.org/10.1108/10748120110424816

Sajtos, L., Mitev, A. (2007) "SPSS Kutatási és adatelemzési kézikönyv" (SPSS reserch and data analysis handbook), Alinea, Budapest. (in Hungarian)

Sági, M. (2010) "Kulturális szegmentáció: "mindenevők", "válogatósak", "egysíkúak" és "nélkülözők"? Az "omnivore-univore" modell alkalmazhatósága Magyarországon" (Cultural segmentation: the omnivorous, the choosy, the one-sided and the indigent? The applicability of the omnivore-univore model), In: Kolosi, T., Tóth, I. Gy. (eds.) Társadalmi riport 2010, Tárki, Budapest, Hungay, pp. 288311. (in Hungarian). [online] Available at: http://www.tarsadalomkutatas.hu/termek.php?termek=TPUBL-A-922 [Accessed: 12 May 2018].

Soltani, A., Pieters, J., Young, J., Sun, Z. (2018) "Exploring city branding strategies and their impacts on local tourism success, the case study of Kumamoto Prefecture, Japan", Asia Pacific Journal of Tourism Research, 23(2), pp. 158-169. https://doi.org/10.1080/10941665.2017.1410195

Székely, L. (2013) "Magyar ifjúság 2012 - Tanulmánykötet" (Hungarian youth 2012 - Monography), Kutatópont, Budapest, Hungary. [online] (in Hungarian). Available at: http://kutatopont.hu/ files/2013/09/Magyar_Ifjusag_2012_tanulmanykotet.pdf [Accessed: 20 April 2018]

Wang, D., Xiang, Z., Fesenmaier, D. R. (2016) "Smartphone Use in Everyday Life and Travel", Journal of Travel Research, 55(1), pp. 52-63. https://doi.org/10.1177/0047287514535847

Z. Karvalics, L. (2016) "Okos városok: a dekonstrukciótól a hiperkonstrukcióig" (Smart cities: from deconstruction to hyperconstruction), Információs Társadalom, 16(3), pp. 9-22. (in Hungarian) https://doi.org/10.22503/inftars.XVI.2016.3.1 